\title{
“Otherness" as the Underlying Principle IN ISRAEL'S ASYLum REgIME
}

\author{
Tally Kritzman-Amir*
}

This Article aims to provide the first thorough description of the developing asylum system in the State of Israel. It argues that despite the inherent moral and doctrinal differences between asylum and immigration regimes, the Israeli asylum system is essentially an extension of Israel's immigration and citizenship regime, which excludes the non-Jewish refugees and frames the refugee as the "other," with the Palestinians and other enemy nationals facing maximum exclusion. While this phenomenon is not uncommon in today's world, which suffers from "compassion fatigue," diluted protection, and adherence to national self-interest, the Israeli example is exceptional for a number of reasons: 1) it came into being only decades after the rest of the democratic developed countries developed their asylum systems; 2) it is rooted in challenging - albeit not exceptional-geo-political conditions; and 3) it works against the background of a very unique immigration law.

\section{INTRODUCTION}

Since 2005, Israel has experienced a mass influx of asylum seekers, entering mostly through its border with Egypt. While Israel has been a party to the Convention Relating to the Status of Refugees ${ }^{1}$ for many decades, the new Israeli asylum system only began functioning in $2002 .^{2}$ Soon thereafter, it was encumbered by a large, rapidly changing number of asylum seekers, growing from a few dozen to a few thousand. Most of the asylum seekers arrive from relatively nearby African countries, namely, Sudan,

*Assistant Professor, The Academic Center for Law and Business. Polonsky Fellow, Van Leer Jerusalem Institute.

I wish to thank the many people with whom I discussed this paper for their valuable comments: Prof. Hadar Aviram, Prof. Eyal Benvenisti, Prof. Ilan Saban, Prof. Stephen Wizner, Adv. Anat Ben Dor, Adv. Yonatan Berman, Adv. Oded Feller, Adv. Ofer Sitbon, and Adv. Noam Weiner. I also wish to thank Amanda Wassermuhl for her thoughtful and attentive editorial work on this Article.

${ }^{1}$ United Nations Convention Relating to the Status of Refugees, Aug. 1, 1951, 189 U.N.T.S. 150, [hereinafter the Refugee Convention].

${ }^{2}$ For an overview of the Israeli asylum system in its formative stage, see ANAT BEN-Dor \& Rami Adut, Israel: a Safe Haven? Problems in the Treatment Offered by the State of Israel to Refugees and Asylum Seekers: Report and Position Paper (2003). 
Eritrea, and Ivory Coast. ${ }^{3}$ Many are nationals of Arab countries, which have a tense relationship with Israel at best. Additionally, the vast majority of asylum seekers have crossed one or more such states on their way to Israel.

Israel is in a challenging normative and geopolitical situation. Normatively, Israel is a nation-state and a self-proclaimed Jewish and democratic state. Geopolitically, Israel is situated close to Africa, between several Muslim and Arab states, some of which are enemies of Israel, and is the only liberal democracy in the region. Israel is also embroiled in an ongoing conflict with the Palestinians in the West Bank and Gaza Strip, and it has a large but marginalized, disempowered and discriminated against Palestinian minority within its borders. ${ }^{4}$ While these geopolitical and normative factors shape the character of the state, they are not unique to Israel. Israel is one of many nation-states that are currently a destination for many immigrants, including Muslims, Arabs, and Africans. Many of these destination countries have securityrelated and demographic concerns.

All of these factors have impacted upon Israel's immigration and citizenship regime. The result is that the Israeli immigration and citizenship regime determines who to exclude and who to include roughly on the basis of a Jewish/other distinction. Israel has a unique jus sanguinis citizenship regime, which displays a significant preference for Jews and their relatives and descendents in the acquisition of citizenship. Israel's regime correlates to an immigration policy that permits immigration almost exclusively to Jews and their relatives, ${ }^{5}$ except for temporary migration for employment, which is heavily governed and restricted by a guest-worker program. ${ }^{6}$ However, different policies allow for the relatively easy annulment of the status of Palestinian residents and citizens $^{7}$ and almost categorically deny any possibility of immigration to Palestinians and citizens of several other Arab countries. ${ }^{8}$

${ }^{3}$ According to recent statistical reports provided by the UNHCR, over 16,000 asylum seekers registered in Israel by the end of 2008. About 4,900 of these asylum seekers were Eritrean nationals, about 4,400 were Sudanese, and approximately 1,700 were originally from Ivory Coast. See email from Michal Alford to Adv. Anat Ben-Dor (Jan. 14, 2009) (on file with author).

${ }^{4}$ See, e.g., Oren Yiftachel, 'Ethnocracy' The Politics of Judaizing Israel/Palestine, 3 Constellations 364 (2002); Sammy Smooha, Minority Status in an Ethnic Democracy: The Status of the Arab Minority in Israel, 13 Ethnic \& Racial Stud. 389 (1999); Yoav Peled, Ethnic Democracy and Legal Construction of Citizenship: Arab Citizens of the Jewish State, 86 Am. Pol. Scr. Rev. 432 (1992).

${ }^{5}$ Law of Return, 1950, S.H. 159; Bill and an Explanatory Note (no. 48), 1950, HH, 189; Nationality Law, 1952, S.H. 146; Draft Bill, (no. 93), 1951, H.H. 22.

${ }^{6}$ On the migration for employment in Israel, see, e.g., Sarah S. Willen, Transnational Migration to Israel in Global Comparative Context (2007).

${ }^{7}$ See, e.g., the Nationality Law, supra note 5, art. 11.

${ }^{8}$ Nationality and Entry into Israel (Temporary Order) Law, 5763-2003, Passed by the Knesset on July 31, 2003, see Nationality and Entry into Israel (Temporary Order) Law, 2003, S.H. 544. 2. 
The recently-developed asylum system in Israel seems to follow, to a large extent, the same logic, despite the fact that international refugee law does not allow taking the above-mention geopolitical situation into consideration. Israel has adopted a narrow reading of Article 1(D) of the Refugee Convention, according to which all Palestinians are ineligible for asylum as potential recipients of UNRWA assistance. ${ }^{9}$ The asylum procedures refer to a broadly-interpreted category of enemy nationals who are excluded from the asylum process, a category which includes all nationals of Arab and Muslim states. ${ }^{10}$ While most asylum seekers are subject to the risk of detention upon their undocumented entry to Israel, asylum seekers who enter Israel after crossing through an Arab country - and in particular those who are nationals of such a country-are to be detained under emergency legislation with access only to informal quasi-judicial review. ${ }^{11}$

This Article argues that these similarities between the asylum regime and the immigration and citizenship regime exist despite the numerous reasons in favor of distinguishing between the different policies. Asylum regimes should be governed by the Refugee Convention and by international humanitarian moral principles, whereas immigration regimes should be governed by the principle of state sovereignty.

Nevertheless, in Israel, the asylum, citizenship, and immigration policies are mainly intended to exclude the "other"--the non-Jewish asylum seeker, and especially

See also, HCJ 7052/03 Adalah-The Legal Center for Arab Minority Rights in Israel v. The Minister of Interior [Feb. 14, 2006] (unpublished) reprinted in, Original petition to the High Court of Justice, Oxford Report on International Law in Domestic Courts (ILDC) 393 (IL 2006).

${ }^{9}$ Refugee Convention, supra note 1, art. 1(D) specifies that

[t]his Convention shall not apply to persons who are at present receiving from organs or agencies of the United Nations other than the United Nations High Commissioner for Refugees protection or assistance. When such protection or assistance has ceased for any reason, without the position of such persons being definitively settled in accordance with the relevant resolutions adopted by the General Assembly of the United Nations, these persons shall ipso facto be entitled to the benefits of this Convention.

See also Michael Kagan \& Anat Ben-Dor, Nowhere to Run: Gay Palestinian Asylum-Seekers in ISRAEL (2008), available at $\mathrm{http} / / / \mathrm{www}$. law.tau.ac.il/Heb/_Uploads/dbsAttachedFiles/NowheretoRun. pdf; LeX TekKenberg, The status of Palestinian RefugeEs in International Law (1998). Finally, see the recently published UN High Commissioner for Refugees, REviSED NOTE ON THE APPLICABILITY OF Article 1D of the 1951 Convention relating to the Status of Refugees to Palestinian Refugees (October 2009), available at http://www.unhcr.org/refworld/docid/4add77d42.html.

${ }^{10}$ Regulations Regarding the Treatment of Asylum Seekers in Israel, art. 6 (2001) (on file with author) [hereinafter the Regulations].

"See Prevention of Infiltration (Offences and Jurisdiction) Law, 1954, S.H. 160; Bill and an Explanatory Note, (no. 161), 1953, H.H. 172. See also the Petition and State Response in HCJ 3208/06, 3270/06, 3271/06, \& 3272/06 Anonymous Petitioners v. The Head of the Israeli Defence Forces Operations [May 8, 2006] (unpublished) (copies of the petition, court decisions, updates, and responses are on file with author). Informal judicial review does take place, as I explain below. 
the Palestinian, the Arab, or the Muslim refugee, regardless of the circumstances that brought them to Israel. While it is not atypical that immigrants are regarded as "others" in nation states, due to Israel's unique character as a nation state these immigrants are more "other" than elsewhere. Immigrants are perceived in a narrow sense and reduced to one overtly dominant characteristic - the national "otherness," in a manner that does not allow them to be perceived as individuals, to be identified with, to be heard, or even to enjoy empathy. It is against this otherness that, the Israeli and Jewish identity are sustained and developed. The "other" asylum seekers—as well as some of the nonJewish immigrants - are suspected of being a security threat, and demography and security considerations merge when "other" asylum seekers are considered. Viewing asylum seekers as "others" constitutes the collective as the anti-force to those "others" and as the unit in which resources should be redistributed (while non-members of the unit are not eligible for a share of those resources). Together, the asylum, immigration, and citizenship policies sustain and enhance the existing social order, excluding or marginalizing asylum seekers (and in particular those who are Palestinian, Arab, or Muslim) and leaving them, at best, the opportunity to participate in Israeli society only through the work market in low-skilled, often undocumented, jobs.

The concept of the "other" or "otherness" is fundamental to different disciplines, including psychology, philosophy, and sociology. This concept has been interpreted and given different meanings, each emphasizing and expanding on a particular angle. Indeed, the perception of immigrants as "others," based on real or imagined differences in physical appearance, culture, norms, values, or membership, has been a basis on which ethno-cultural positions were formed. According to these differences, exclusionary decisions are made and exclusionary measures are applied. ${ }^{12}$ The "others" are, as a result of their "otherness" and their exclusion, a hybrid, physically present but not members. ${ }^{13}$ The "we-ness," the national identity, values, status, and so on are constituted, reinforced, or reshaped against and with reference to the "otherness" of the "other," and the "other" challenges the "self."14 A dichotomy of "us" and "them"15

${ }^{12}$ See, e.g., Rinus Penninx, Immigrants and the Dynamics of Social Exclusion: Lessons for AntiDiscrimination Policies, in Dedication and Detachment: Essays IN Honour of Hans Vermeulen 193 (Flip Lindo, Onbekend, Mies van Niekerk, \& Hans Vermeulen eds., 2001).

${ }^{13}$ Zygmund Bauman, Modernity and Ambivalence 58 (1991).

${ }^{14}$ Stuart Hall, Introduction: Who Needs Identity?, in Questions of CULTURAL IDENTITY 4-5 (Stuart Hall \& Paul Du Gay eds., 1996); Gerard Delanty, Citizenship in a Global Age: Society, Culture, Politics 115 (2000). This Article refers to the constitution of the "we-ness" only indirectly within its limited scope as the flip side of the coin of the formation of the "otherness."

${ }^{15}$ This dichotomy has been critiqued in the feminist critique of international law. See, e.g., Ann Tickner, Gender In International Relations 64-65 (1992); Saskia Sassen, Is This the Way to 
shapes class relations and notions of belonging, and "they" are often associated with perceptions of risks, ${ }^{16}$ threats, ${ }^{17}$ and chaos. ${ }^{18}$

This Article applies some ideas from the robust discussion of the term "other" to the current context, in order to explain and characterize the perception of refugees in Israeli society. Part I of this Article elaborates on the Israeli immigration and citizenship regime and shows how this regime favors and includes Jews while discriminating against and excluding non-Jews, with exclusion reaching its height with respect to Palestinians and enemy nationals. Part II describes the difference between the immigration regime and the asylum regime, which operate under different assumptions and different sets of values, suggesting that they would be significantly different from each other. Part III describes the Israeli asylum system and shows that it is applied in parallel to the immigration and citizenship regime and follows the latter's logic to a large extent. This section examines how under the asylum regime the refugee is portrayed as the "other," with Palestinian and Arab asylum seekers being the extreme embodiment of "otherness."

\section{The Israeli Immigration and Citizenship Regime: Advantaged Jews, Disadvantaged Palestinians}

It is important to understand Israel's asylum regime in light of its immigration and citizenship norms. In short, these norms can be categorized as benefitting Jews and extremely disadvantaging and excluding Arabs from neighboring countries and Palestinians from the West Bank and Gaza. The purpose of those norms is to strengthen the Jewish "we-ness," and to form a collective Israeli nationhood, against the threats posed by the "other."19

The fundamental component of Israel's immigration laws is the Law of Return, the general premise of which is that "[e]very Jew has the right to come to this country as an oleh [one who ascends, a Jewish newcomer to the land of Israel]." ${ }^{20}$ This notion corresponds to the nature of Israel as a Jewish and democratic state, as proclaimed

Go?-Handling Immigration in a Global Era, 4 STAN. AgORA 1 (2003).

${ }^{16}$ See, e.g., Penninx, supra note 12; Zygmund Bauman, Modernity and the Holocaust $52 \mathrm{ff}$. (1989).

${ }^{17}$ Zygmund Bauman, Postmodernity and Its Discontent 17 (1997).

${ }^{18}$ BAUMAN, supra note 13 , at 15.

${ }^{19}$ See supra note 15; see also Ian Lustick, Israel as a Non-Arab State: The Political Implications of Mass Immigration of Non-Jews, 53 MiD. E. J. 417 (1999).

${ }^{20}$ Law of Return, supra note 5, art. 1. 
in its declaration of independence ${ }^{21}$ and in Israel's basic laws, ${ }^{22}$ which both manifest Israel's efforts to maintain a Jewish majority. ${ }^{23}$ According to both early and current discussions of the Knesset (Israeli Parliament), ${ }^{24}$ courts $^{25}$ and policy debates, ${ }^{26}$ these legislative instruments define Israel as an Aliyah state—a state of Jewish return-rather than an immigration state. The scope of the category of those who are eligible for return was debated by the Israeli Supreme Court, sitting as the High Court of Justice (HCJ), ${ }^{27}$ but eventually the 1970 amendment to the Law of Return determined the right to include a broad category of descendents of Jews and their family members. ${ }^{28}$ Inadvertently through this amendment, tens of thousands of persons, who are not considered Jewish under Jewish law or according to their own self-definition, may immigrate to Israel, most of which came during the 1990s from the former Soviet Union. According to some studies, these individuals serve as a "demographic counterforce" to the Palestinian minority in Israel. ${ }^{29}$ This is especially true given the Israeli refusal to recognize the right of return of Palestinian refugees. ${ }^{30}$ The morality of the Law of Return has been discussed in numerous scholarly debates, ${ }^{31}$ and falls beyond

${ }^{21}$ Published in the Official Gazette, No. 1 of the 5th of Iyar, 5708 (May 14, 1948), available at $\mathrm{http}: / /$ www.mfa.gov.il/MFA/Peace+Process/Guide+to+the+Peace+Process/Declaration+of+Establis hment + of + State + of + Israel.htm.

${ }^{22}$ See, e.g., the Basic Law: Human Dignity and Liberty, art. 1, S.H. 1391, according to which "[t]he purpose of this Basic Law is to protect human dignity and liberty, in order to establish in a Basic Law the values of the State of Israel as a Jewish and democratic state."; Bill and an Explanatory Note (no. 2086), HH, 1992, 60, available at http://www.knesset.gov.il/laws/special/eng/basic3_eng. htm.

${ }^{23}$ On the connection between being an Israeli state and maintaining a Jewish majority in Israel, see the Interim Report of the Advisory Committee on IsRael's Immigration Policy 3-6 (Feb. 7, 2006) [in Hebrew] (copy on file with author). This committee was appointed by the former minister of interior and headed by Prof. Amnon Rubinstein.

${ }^{24}$ See e.g., the discussion following the second and third vote on the Law of Return in the Israeli Parliament, Aug. 27, 1952, 12 DK (1952) 3167.

${ }^{25}$ See, e.g., AdmA 1644/05 Nikolay Frida v. The Ministry of Interior [June 29, 2005] (unpublished).

${ }^{26}$ See supra note 23.

${ }^{27}$ HCJ 72/62 Rufaizen v. The Minister of Interior [1962] IsrSC 16 2428; HCJ 56/68 Kendel v. The Minister of Interior [1968] IsrSC 23(2) 477.

${ }^{28}$ Law of Return, supra note 5, arts. 4a \& 4b.

${ }^{29}$ Lustick, supra note 19, at 101.

${ }^{30}$ See, e.g., Chaim Gans, The Palestinian Right of Return and the Justice of Zionism, 5 Theoretical InQ. L. (2004), available at http://www.bepress.com/til/default/vol5/iss $2 /$ art2/; Alon Harel, Whose Home Is It? Reflections on the Palestinians'Interest in Return, 5 THEORETICAL INQ. L. (2004), available at $\mathrm{http} / / / \mathrm{www}$. bepress.com/til/default/vol5/iss $2 /$ art5.

${ }^{31}$ See, e.g., Chaim Gans, Nationalist Priorities and Restrictions in Immigration: The Case of Israel, 2 L. \& Eтнісs Huм. RTs. (2008), available at http://www.bepress.com/cgi/viewcontent.cgi?a rticle $=1024 \&$ context $=$ lehr. 
the scope of this Article. It should be noted, however, that irrespective of the view one holds on the morality of the Law of Return, under the Israeli immigration regime, nonJews do not have a right to immigrate to Israel, and their entry to the state is restricted by the Entry to Israel Law. ${ }^{32}$ Since the 1990s, most non-Jewish immigrants can only come to Israel as temporary migrant workers,$^{33}$ who are essentially excluded from the Israeli welfare system ${ }^{34}$ and are commonly marginalized and often exploited..$^{35}$ More specifically, the ability of Palestinians and Arabs to immigrate, even just temporarily, to Israel, has been restricted by recent legislation, upheld by a slim majority in the Supreme Court. ${ }^{36}$

Under the complementing naturalization norms, namely the Nationality Law, citizenship is granted automatically to those who immigrate to Israel under the Law of Return. Non-returnees have a limited ability to acquire citizenship. ${ }^{37}$ For many years, the ability of non-Jews who resided in Israel prior to its independence and their descendents to acquire Israeli citizenship was restricted ${ }^{38}$ since those who fled Israel during the $1948 \mathrm{War}^{39}$ were ineligible for citizenship. The ability of stateless persons to acquire citizenship in Israel, ${ }^{40}$ as per Israel's commitment under international law, ${ }^{41}$ was limited by the Nationality Law itself and is almost theoretical since regulations on acquisition of citizenship for stateless persons were never set, despite a court order on the matter. ${ }^{42}$ Naturalization efforts encounter difficulties because despite the efforts 134.

${ }^{32}$ Entry into Israel Law, 1952, S.H. 111; Bill and an Explanatory Note (no. 106), 1952, H.H.,

${ }^{33}$ On the migration for employment in Israel, see, e.g. WILLEN, supra note 6.

${ }^{34}$ Migrant workers are eligible for some- though not all-social security benefits. Children of migrant workers are eligible for partially state-sponsored health care (though they are excluded from the national health care system) and can attend the public school system.

${ }^{35}$ On the structural exploitative scheme of employment of migrant workers, see HCJ 4542/02 Kav La'oved Association v. Israel [March 30, 2006] (unpublished); original petition to the High Court of Justice is translated in ILDC 382 (IL 2006).

${ }^{36}$ Adalah $v$. The Minister of Interior, supra note 8.

${ }^{37}$ Law of Return, supra note 5, arts. 2.

${ }^{38} I$ Id. arts. $3 \&$ a

${ }^{39}$ The question of whether the Palestinians fled Israel voluntarily or whether they were forced to leave by the State of Israel has been well-debated by historians and falls beyond the scope of this paper. See generally Benny Morris, The Birth of the Palestinian Refugee Problem, 1947-1949 (1989).

${ }^{40}$ Law of Return, supra note 5, art. 4a.

${ }^{41}$ Israel is a party to the 1961 Convention on the Reduction of Statelessness, Aug. 30, 1961, 989 U.N.T.S. 175.

${ }^{42}$ In AdmApp (Tel Aviv) 2887/05 Elkasayev v. The Minister of Interior Affairs [Jan. 29, 2007] (unpublished), the court ordered the Ministry of Interior to enact regulations on the process through which stateless persons can acquire citizenship in Israel. 
of courts to facilitate naturalization, ${ }^{43}$ the process is governed by constantly changing, non-transparent, ${ }^{44}$ and exclusionary regulations. ${ }^{45}$ Perhaps most importantly, the possibility of naturalization for Palestinians and Arabs has been almost completely blocked by recent legislation, except in rare and exceptional circumstances. ${ }^{46}$

Finally, it should also be mentioned that Palestinians are more likely to lose their citizenship or residency status, since one of the grounds on which status may be revoked is entering into enemy countries or acquiring citizenship in one of those countries, in which many of the Palestinian citizens of Israel have family ties or other affiliations. ${ }^{47}$ Calls for broadening the authority to revoke the citizenship of Palestinians are often heard within the judicial process and public debate, ${ }^{48}$ and the few rare occasions on which citizenship has been revoked involved Palestinian citizens. ${ }^{49}$ It should also be noted that a significant number of non-Jews do not have citizenship status, but rather hold an inferior residency status, which they can easily lose if they relocate, even temporarily, to another country, ${ }^{50}$ and

${ }^{43}$ On the courts' attempts to simplify and shorten the naturalization process for family members of citizens, see HCJ 3648/97 Stamka v. The Minister of Interior [1999] IsrSC 53(2) 728; Adm. App.4614/05 The Minister of Interior v. Oren [Mar. 16, 2006] (unpublished). See also Adm.Pet. 2790/04 Rozenberg v. The Minister of Interior [Dec. 29, 2004] (unpublished).

${ }^{44}$ Adm.Pet. 530/07 The Association for Civil Rights in Israel v. The Ministry of Interior [Dec. 5, 2007] (unpublished).

45 See, e.g., The Procedure on Treatment of Partners of Israel Citizens, Including SameSex Partners, Procedure (Feb. 5, 2009), available at http://www.moin.gov.il/Apps/PubWebSite/ publications.nsf/All/9CD5C9CFC6C82B85422570AD00431263/\$FILE/Publications.2.0009\%2010.8.09doc.pdf?OpenElement.

${ }^{46}$ Nationality and Entry into Israel, supra note 8 . The existence of such rare and exceptional circumstances is supposed to be considered by a committee. It remains unclear whether this committee does, in fact, convene and make such decisions.

${ }^{47}$ Law of Return, supra note 5, art. 11.

${ }^{48}$ See, e.g., HCJ 2934/07 Israel Law Center v. The Chair Person of the Knesset [Sept. 16, 2007] (unpublished).

${ }^{49}$ Letter from Adv. Oded Feller, Association of Civil Rights in Israel, to the Legal Advisor of the Ministry of Interior 6 (Jan. 10, 2007) (on file with author). See also, e.g., HCJ 2271/98 Dunia Zad Ahmed Muhammad Abed Hathut v. The Minister of Interior [2001] IsrSC 51(1) 458. It should also be mentioned that while there were efforts to revoke status of Palestinians who rightfully gained their status, occasionally, citizenship is revoked to those who acquired it under false pretense. This is not done exclusively for Palestinians, but also for persons who claimed to be Jewish. See, e.g., HCJ 713/00 David Adishvili v. The Ministry of Interior [Mar. 19, 2001] (unpublished); HCJ 754/83 Christopher Mark Rankin v. The Minister of Interior [Nov. 16, 1984] (unpublished).

${ }^{50}$ See, e.g., Adm.Pet. (Jerusalem) 384/07 Hatem Siaj v. The Minister of Interior [2008] (unpublished) (regarding the loss of residency of a person who left Israel to study abroad); Adm. Pet. (Jerusalem) 247/07 Omri v. The Minister of Interior [2007] (unpublished) (regarding the loss of residency of a person who left Israel to live with a spouse in his country of citizenship and wanted to regain his residency following their divorce). 
which carries only limited rights and partial participation in the Israeli welfare system. ${ }^{51}$

In other words, Israel's immigration and citizenship regime privilege Jews and their relatives and offers them immediate inclusion, status, and full participation in the welfare system. The non-Jew is generally excluded or offered a limited and difficult ability to be included. The most limited opportunity to immigrate and acquire status is offered to Palestinians. These regimes fulfill the self-proclaimed nature-and maybe even the raison d'être - of Israel as a Jewish-democratic state. Under this structure, the "other"-i.e., the non-Jew, whose epitome is the Palestinian or Arab -cannot possibly be included except in rare circumstances or while being marginalized, excluded, or exploited in the employment market. It is against the exclusion of the "other" that the Jewish "self" is formed and sustained. ${ }^{52}$

\section{Between the Immigration and Citizenship Regime and the AsYlum Regime}

It is interesting to compare Israel's immigration and citizenship regime with the asylum regime, since the underlying logic of these two systems is supposed to be so fundamentally different. The reason for the distinction is that while immigration is restricted by the principle of state sovereignty, asylum is governed by international legal obligations.

With respect to immigration, states as sovereign entities are currently perceived to be entitled to decide whom to include and whom to exclude from their territories, with international legal restrictions playing a minimal role in the decision-making process. The sovereign power of states also enables them to close their borders and to banish undesired intruders. Typically, states allow immigration when, and to the extent that, it meets the self-interests of their nations. In fact, states are perceived to have the right-and perhaps even the duty-to do just that. This is the reason immigration issues are debated in the political arena and are often determinative of election results. In the case of Israel, the self-interest of the state in maintaining a certain identity and demographic balance shapes these decisions.

While immigration policy is governed by the principle of sovereignty, refugee law is an exception that is governed by international legal obligations. The Refugee

\footnotetext{
${ }^{51}$ It should be noted that the status of Palestinians residing in East Jerusalem is slightly different. However, this falls outside the scope of this discussion. See THE Association OF CIVIL RIGHTS IN Israel, The State of Human Rights in East Jerusalem: Facts and Figures (May 2009) available at http://www.acri.org.il/pdf/eastjer2009.pdf.

${ }^{52}$ See supra note 15.
} 
Convention provides that states should make a reciprocal commitment to protect refugees. The Refugee Convention defines the legal category of "refugee," explaining that refugees are believed to be different from "ordinary" immigrants, and as such more deserving of international protection. A refugee is defined in the Refugee Convention, essentially as a person who "owing to well-founded fear of being persecuted for reasons of race, religion, nationality, membership of a particular social group or political opinion, is outside the country of his nationality and is unable or, owing to such fear, is unwilling to avail himself of the protection of that country." 53 The state owes a duty to refrain from returning such persons to any other country where their life or liberty is in danger. ${ }^{54}$ The state also owes an additional duty to guarantee the refugee's other civil and socio-economic rights. ${ }^{55}$ It should therefore be noted that Israel is bound by international law in its treatment of refugees.

Thus, while states are free to make decisions on whom to exclude, whom to include, and what degree of membership should be granted within the immigration context, in the asylum context states are limited in their ability to make such determinations by international law. While a state can decide not to include immigrants at all, a state that is party to the Refugee Convention has to include the refugees to some extent, in order to provide them the protection and social and economic rights mentioned above.

This formal difference stems from a moral difference between immigrants and refugees. While immigrants choose to leave their countries of origin and can also choose to return to them, ${ }^{56}$ refugees leave their countries as a result of extreme necessity, ${ }^{57}$ are unable or unwilling to expose themselves to their states' protection, ${ }^{58}$

${ }^{53}$ The Refugee Convention, supra note 1, at art. 1(A)(2).

${ }^{54}$ Id. art. 33.

${ }^{55}$ See, e.g., id. art. 4 (freedom of religion); arts. 13-15 (property rights); arts. 17-19 (employment rights); arts. 2-23 (welfare and education rights); etc.

${ }^{56}$ This perception is often a bit unclear, since decisions to immigrate can often be categorized as difficult choices at best. On the distinction between coerced choices and difficult choices in immigration, see, e.g., Harry Beran, What is the Basis for Political Authority?, 66 Monss 479, 497-98 (1983). Beran makes this distinction in a different context; namely, discussing whether an individual's choice to immigrate or to refrain from immigrating could and should be understood as an implied consent to the social contract. Similarly, David Hume commented that many do not have the choice to immigrate as they have been denied freedom of movement. He is also often quote saying, "Can we seriously say that a poor peasant or artisan has a free choice to leave his country, when he knows no foreign language or manners, and lives from day to day on small wages which he acquires?" See David Hume, Of the Original Contract, in HumE's Moral and Poltitical Philosophy 363-64 (Henry David Aiken ed., 1948). It should be noted that Hume made this remark in the context of a discussion about the duty to obey the law.

57 On the concept of necessity in immigration, see NiRAJ NATHWAN, RETHINKING Refugee LaW 27-28 (2003). It should be noted that there are other immigrants who are in refugee-like situations 
and need surrogate protection from the countries in which they seek asylum. ${ }^{59}$

Accordingly, and to the extent that states are assumed to follow their moral and international legal obligations, they can be expected to be more generous, including, and open toward refugees than towards immigrants. "Otherness" is not expected to prevail in the context of asylum regimes as much as it does in the context of immigration and citizenship regime.

\section{The Israeli Asylum Regime: Construing the Refugee as the "OTHER"}

How does Israel's asylum regime compare with its immigration and citizenship regime in its treatment of the non-Jew, and in particular, the Arab or Palestinian? Israel was one of the active participants in the drafting of the Refugee Convention and had a serious interest in seeing that it materialized, especially because the Convention was perceived to be potentially helpful to the Jewish refugees of the Second World War. ${ }^{60}$ In this context, one may expect a high degree of moral commitment toward asylum seekers, coupled with a strong sense of empathy and an ability to identify with victims of persecution.

Given the blanket protection that the Law of Return provides to all Jewish immigrants - refugees and non-refugees - the Refugee Convention was never applied within Israel with respect to Jewish refugees. ${ }^{61}$ Therefore, the Israeli asylum regime

and whose immigration is a result of extreme necessity, that are currently not classified as refugees, such as victims of natural disasters, civil wars, general violence, etc. For the sake of simplicity, the Article only refers to refugees. For further elaboration on the limits of the boundaries of the category of refugees see Tally Kritzman-Amir, Socio-Economic Refugees (2009) (unpublished PhD Dissertation, Tel Aviv University ) (on file with the author).

${ }^{58}$ Refugee Convention, supra note 1 , arts. $1(\mathrm{~A})(2)$ and $1(\mathrm{C})$, which refers to a person "who is able to invoke compelling reasons arising out of previous persecution for refusing to return to the country of his former habitual residence." This exception to the cessation of status was originally intended to apply to Holocaust refugees, but it was recently purposively interpreted by the United Nations High Commissioner for Refugees (UNHCR) to "cover cases where refugees, or their family members, have suffered atrocious forms of persecution and therefore cannot be expected to return to the country of origin or former habitual residence." UNHCR Guidelines, International Protection: Cessation of Refugee Status under Article $1 C(5)$ and (6) of the 1951 Convention Relating to the Status of Refugees (the 'Ceased Circumstances' Clauses), (2003) 6 (ss. 20-21) (Feb. 10, 2003).

${ }^{59}$ James C. Hathaway, The Law of Refugee Status 135 (1991).

${ }^{60}$ See, e.g., Holly Buchanan, Escape from Darfur: Why Israel Needs to Adopt a Comprehensive Domestic Refugee Law, 11 ChaP. L. Rev. 601, 611-12 (2008).

${ }^{61}$ Jewish refugees are treated by the Law of Return. See Law of Return, supra note 5. 
is essentially designed for non-Jews, those who would be labeled as the "other" under the immigration and citizenship regime. However, the vast difference between the morality of refugee protection under the asylum regime and the ordinary rules of immigration under the immigration and citizenship regime may lead us to expect that the non-Jewish refugee would be included in Israeli society, at least to the extent of receiving protection if not to the extent of full participation in the society. In fact, we can see that in many countries the fundamental difference between the asylum regime and the immigration regime is accepted and refugees are indeed protected and accepted into society. Nevertheless, as is demonstrated below, several components of the architecture of the Israeli asylum regime assume or re-emphasize the "otherness" of the refugee.

\section{A. LAWlessness, Temporariness, AND EXClusion OF THE "OtheR"}

Despite Israel's historical commitment to the Refugee Convention, which it signed in 1951 and ratified as early as 1954 , very little has been done to implement this convention in Israel. In spite of recent sporadic attempts, Israel has yet to incorporate it into domestic law ${ }^{62}$ and has only in 2002 established a clear procedure for screening asylum seekers, in the form of a set of regulations (rather than primary legislation). ${ }^{63}$

${ }^{62}$ A number of attempts to legislate the Refugee Rights Law failed during the last few years. These attempts were led by Knesset members Dov Hanin and Ofir Pinnes and included a partial and lacking protection of refugee rights. Due to the lack of willingness of other parliament members to support these bills, they were never enacted.

${ }^{63}$ Regulations, supra note 10 . It should be noted that although these norms have been referred to as regulations in the literature, they are, in fact, internal procedures - that is, of inferior normative power than regulations. This Article refers to them as regulations, despite the inaccuracy, for the sake of consistency. Under the current refugee regime, which was established under the administrative procedure in 2001 by an inter-governmental committee, Israel is not fully involved in the status determination process. Instead, since 2002 , the initial screening of asylum applications is conducted by the UNHCR representative to Israel, who makes a recommendation on each case and delivers it to an inter-ministerial committee called the National Status Granting Body (NSGB). This committee, which includes representatives from the Ministries of Justice, Foreign Affairs, and Interior, in turn makes a recommendation to the Minister of Interior, who has the authority to grant the request and give status to the asylum seeker. This process lasts a few months - and in some cases, years-during which time the asylum seeker is given a letter from the UNHCR that gives her protection from removal and deportation and, in some cases, also permission to work. The prolonged RSD process was described in the latest State's Comptroller and Ombudsman's report a summary can be found at http://www.mevaker.gov.il (last visited Dec. 16, 2009) [in Hebrew]. While it is unclear why Israel allowed the UNHCR to play a dominant role in the RSD process, this could be a result of lack of expertise on the Israeli side. The above-mention status determination process has many procedural 
Under Israel's dualist legal system, the failure to incorporate the Refugee Convention into Israeli domestic law means that it is not a legally binding document that could serve as a basis for individuals to make claims in Israeli domestic courts. ${ }^{64}$

Under the new regulations, a recognized refugee, of which there are only a few dozen in Israel, ${ }^{65}$ is granted temporary residency status. ${ }^{66}$ It is important to note that there is no designated refugee status, but rather refugees are granted a "generic" status that is given to other temporary stayers or persons in the process of naturalization in Israel. Where status is concerned, the uniqueness of the circumstances that led to its being granted is diminished and not clearly conveyed in a separate status for refugee. ${ }^{67}$

Additionally, as a practical matter, ${ }^{68}$ refugees are unable to naturalize and gain a permanent status. ${ }^{69}$ While granting permanent status is not a requirement of the

flaws. Notably, asylees do not have a right to be represented by an attorney before the UNHCR or the committee. In addition, the possibility to appeal a decision is very limited, because the reasons for rejecting an asylum request are either not given to asylees or are only briefly stated. And appeals are heard by the same persons in the UNHCR correspondent office who made the original decision. Finally, since it was never published, many asylum seekers don't know about the asylum procedure, Since July 2009 , Israel started operating an RSD unit, which is supposed to gradually take over the responsibilities assumed by the UNHCR, but to date has done a relatively small number of RSD interviews. It is still too early to evaluate the operation of this unit.

${ }^{64}$ This does not mean that the Refugee Convention does not have any legal meaning in Israel. The Regulations refer to the Refugee Convention. Due to a "conformity presumption, Israeli courts will always prefer to interpret legislation in a manner it conforms to the Refugee Convention, rather than interpreting it in a manner it contradicts the Refugee Convention." On this presumption, see, e.g., CrA 6182/98 Shienbien v. The Government's Legal Council [1999] IsrSC 53(1) 625; HCJ 279/51 Amsterdam v. The Minister of Finance [1952] IsrSC 6 945; HCJ 279/51 [1952] IsrSC 6 945, 966 (1952).

${ }^{65}$ Up until February 2009, Israel has granted refugee status to about 170 asylum seekers. See Refugee Rights Seekers Forum, Asylum Seekers and Refugees IN Israel (2009), available at http://www.acri.org.il/pdf/refugees0209.pdf [in Hebrew]. Others are considered to be in a refugeelike situation, and are not granted recognition. This policy has harsh implications on the day-to-day lives of these persons. It should be noted that the Refugee Convention remains vague and does not spell out a requirement for states to recognize of refugees as such.

${ }^{66}$ See Regulations, supra note 10, art. 3(D) and the current Procedure on the Treatment of Asylum Seekers in Israel, and of Persons who were Recognized as Deserving of Asylum by the Minister of Interior, art. C(3), available at http://www.moin.gov.il/Apps/PubWebSite/publications. nsf/All/A5C1B2D4AD341823422570AD004311F4/\$FILE/Publications.2.0012.pdf?OpenElement [in Hebrew] (last visited Dec. 16, 2009).

${ }^{67}$ While this could potentially be a positive step that prevents discrimination, it also prevents affirmative action, such as the taking into consideration of the special trauma, hardship, and physical difficulties the refugees have gone through.

${ }^{68}$ There are no legal barriers preventing the Minister of Interior from naturalizing a refugee, however, no minister has ever exercised the discretion to do so.

${ }^{69}$ On the relationship between citizenship, refugee status, and rights see HANNAH ARENDT, THE Origins OF TOtaLITARIANISM 292-93 (1973). 
Refugee Convention, many countries set a unique procedure under specific regulations for the granting of refugee status, and for naturalization of refugees over time. ${ }^{70} \mathrm{~A}$ side effect of the temporary status is that refugees are unable to fully participate in Israeli society, politics, and welfare system. ${ }^{71}$ Also, the inability to obtain permanency prevents refugees from finding a much-needed sense of stability in their lives. ${ }^{72}$

More importantly, unlike in other countries, the application of the existing regulations is often suspended, as the Refugee Status Determination (RSD) process is not conducted with respect to most asylum seekers, with persons from specific countries of nationality not being granted access to the Israeli asylum system. Essentially, nationals of countries of origin from which a large number of asylum seekers come (such as Eritrea and Sudan) are not being processed through the RSD system, ${ }^{73}$ but rather are offered a weak form of temporary group protection ${ }^{74}$

The result of the inability to acquire official recognition as a refugee is that refugees are vulnerable to frequent changes of policies and do not enjoy stability. Most of the refugees are left exposed, in legal limbo, though they apply for status and hope to undergo RSD. In an effort to give them some protection from detention

${ }^{70}$ Compare with the policy in the United States, defined in the Immigration and Nationality Act, arts. 209(b) and 316(a), 8 U.S.C. 1159 and 8 U.S.C. 1427, (determining naturalization of refugees to permanent residents and then to citizens in the United States); and with European Council Directive 2003/109/EC of Nov. 25, 2003 concerning the status of third-country nationals who are long-term residents.

${ }^{71}$ The Refugee Convention includes specific "soft" duties of states to provide social and economic rights to refugees, but as mentioned, above, Israel refrains from recognizing most asylum seekers as refugees. The Refugee Convention does not specify the rights of asylum seekers as such. All asylum seekers in Israeli are eligible to receive emergency health care. Moreover, if they receive a work permit and are employed, they are entitled to private health insurance, which is paid for by their employers, and some social security benefits. Children of asylum seekers are eligible for discounted and partially state-sponsored private health insurance and are allowed to join the education system. Many asylum seekers are not granted a formal work permit, either until the completion of the initial status of their Refugee Status Determination or at all, and support themselves by seeking undocumented employment or by depending on charity. Recognized refugees receive the same rights as temporary residents, and as such are included in the national health insurance system and eligible for more social security benefits. It seems that the case of social and economic rights of asylum seekers and refugees reflects the general situation of social and economic rights in Israel, which are uncodified and, due to lack of consensus on their scope, not specifically included in Israel's basic rights. See also ARENDT, supra note 69, at 292-93.

${ }^{72}$ See Tally Kritzman-Amir \& Adriana Kemp, Refugees and Asylum Seekers in Israel: Between the Administrative Procedure and the Civil Society, MishPat HeVRA VE'TARBut 55 (2008) [in Hebrew].

${ }^{73}$ See Letter from the UNHCR office in Tel Aviv, Status and Protection of Asylum Seekers in Israel-Explanations and Updates, (Aug. 12, 2008) [in Hebrew] (on file with author).

${ }^{74}$ See infra, section B. 
and deportation, the United Nations High Commissioner for Refugees (UNHCR) has developed an elaborate and unique system of quasi-official protection papers that are handed out to asylum seekers. ${ }^{75}$ These papers are often-though not alwaysrespected as proof of a person's need for UNHCR protection, and only occasionally do mass detentions and small-scale deportations of persons with UNHCR protection papers occur. In addition, these quasi-official papers do not grant participation in the Israeli welfare system, nor do they allow documented employment. Caught in this state of legal limbo and having to make ends meet, refugees are therefore pushed to find undocumented employment.

As can be inferred from the description above, the presence of refugees in Israel is chaotic. $^{76}$ They are physically present in Israel, but to a large extent legally absent, as in most cases they lack formal status and welfare rights. ${ }^{77}$

\section{B. Group-Based Protection and the Impersonal “Other”}

As mentioned above, most asylum requests in Israel are not processed through the RSD system. Instead they are granted a group-based and often informal temporary protection.

Group-based informal temporary protection was granted even in the earlier days prior to the formation of the Israeli asylum system. ${ }^{78}$ But even after the asylum system was established, Israel has continued to extend group-based protection. Nationals of a few countries, such as Ivory Coast, Liberia, ${ }^{79}$ the Democratic Republic of Congo, Sierra Leone ${ }^{80}$ and Togo, have received formal temporary protection following a government

${ }^{75}$ There are at least four types of "protection papers," each entailing a different scope of protection. For example, according to a fragile understanding with the Ministry of Labor and Industry, persons with one type of "protection paper" are employable. On this protection paper system and its disadvantages, see Letter from Adv. Yonatan Berman, Hotline for Migrant Workers, to Michael Bavli, Head of the UNHCR office in Jerusalem, Detention of Asylum Seekers who approached the UNHCR, (March 4, 2008) and Michael Bavli's response (March 6, 2008).

${ }^{76}$ On chaos and otherness, see BAUMAN, supra note 13 , at 15.

${ }^{77}$ Interestingly, and perhaps surprisingly, Zygmund Bauman made a similar distinction with respect to Jews in Europe prior to the Holocaust. See supra note 16.

${ }^{78}$ On group protection of Vietnamese, Southern Lebanese, and others, see Ben Herzog, Zionist Humanism: The Glocality of the Debate over Refuge in Israel (2003) (unpublished Ph.D. dissertation, Tel Aviv University) (on file with author).

${ }^{79}$ Temporary protection for Liberians was terminated in 2007. See Dan Izenberg, Liberia Asks Israel to Let its Refugees Stay, Jerusalem Post, Feb. 27, 2007, available at http://www.jpost.com/ servlet/Satellite?pagename=JPost\%2FJPArticle\%2FShowFull\&cid=1171894534035.

${ }^{80}$ Temporary protection for Sierra Leonese was terminated in 2005. See Ina Friedman, Israel Preps Sierra Leone Refugees to Return Home, July 25, 2005, JeRUSALEM RePORT. 
decision labeling their countries of origin as "countries in crisis." countries, such as Eritrea and Myanmar, have received informal temporary protection, since Israel's diplomatic interests have prevented declaring that these countries are "in crisis." $" 82$ In effect, despite their exclusion under the asylum regulations, the protection from deportation extended to Sudanese refugees may be perceived as a thin form of de facto temporary protection. The nature and scope of the protection varies between different nationalities. While there are no accurate findings to prove so, it seems that at least potentially, many of the nationals of these countries could qualify as refugees, and the vast majority of them are in refugee-like situations. ${ }^{83}$

The tendency to provide temporary protection rather than the kind of protection the Refugee Convention demands is common to many countries today. ${ }^{84}$ However, in many of the other countries, temporary protection provides protection to persons who may not have received protection otherwise, as they do not fall under the definition of "refugee," whereas in Israel group protection is given also to persons who might be eligible for individual protection as refugees. Temporary protection is critiqued since it grants essentially fewer rights to all of those protected (some of whom could have received a broader set of rights and could have naturalized had they had access to the RSD system, rather than to the temporary protection system). ${ }^{85}$ Additional critique

81 See Tally Kritzman, Paper presented to the Association for Israel Studies 23rd Annual Conference, Israel as an Immigrant Society: Between the Melting Pot and Multiculturalism: Israel as a State of Temporary Asylum (June 11-13, 2007) (on file with author).

${ }^{82}$ On the government decision to grant temporary protection, see Asylum Seekers and Refugees in Israel, available at http://www.acri.org.il/Story.aspx?id=1878 [in Hebrew] (last visited Dec. 16, 2009).

${ }^{83}$ The vast majority of the asylum seekers in Israel arrive from Sudan and Eritrea. Those arriving from Eritrea have escaped forced prescription, religious persecution, and other human rights violations. Those arriving from Sudan have escaped the difficult crisis, often referred to as genocide, in Darfur, the civil war in South Sudan, and tribal or religious persecution. Asylum seekers from both nationalities are likely to face persecution if returned to their country of origin. See United Kingdom: Home Office, Operational Guidance Note: Sudan, Nov. 2, 2009 (describing the situation in the Sudan), available at http://www.unhcr.org/refworld/docid/4aeecfca2.html; see United Kingdom: Home Office, Country of Origin Information Report-Eritrea, Oct. 13, 2009 (describing on the situation in Eritrea) available at http://www.unhcr.org/refworld/docid/4adc1b972. html (see particularly Section 33 on the Treatment of Returned Asylum Seekers).

${ }^{84}$ Joan Fitzpatrick, Temporary Protection of Refugees: Elements of a Formalized Regime, 94 AM. J. INT'L L. 279 (2000). See also Joseph Pugliese, The Incommensurability of Law to Justice: Refugees and Australia's Temporary Protection Visa, 16. L. \& LIT. 285, 296-98 (2004); Scott Reynolds, European Council Directive 2001/55/EC: Toward a Common European Asylum System, 8 CoLuM. J. EuR. L. 359, 360 (2002); Randall Hansen, Susan Martin, Andrew Scheonholtz, \& Patrick Weil, Report on the Workshop on Refugee and Asylum Policy in Practice in Europe and North America, 14 Geo. Immigration. L.J. 801, 808-09 (2000).

${ }^{85} \mathrm{Id}$. at $291 \mathrm{ff}$. 
points to the fact that whereas there must be clear standards for the termination of the protection of refugees ${ }^{86}$ there are no such standards for the termination of temporary protection. ${ }^{87}$ Therefore, while Israel grants temporary protection, at the same time it also prevents persons from the countries of origin to the nationals of which temporary protection is granted from having access to the rights that they would enjoy had they been recognized as refugees and ensures that their protection is easy to terminate.

In addition to ensuring the complex inclusion/exclusion situation of protected persons, granting temporary protection also allows states to avoid dealing with individual persons, since they are handled as members of their group of nationality. Individuals do not need to tell their stories and establish a well-founded fear of persecution; rather, they oftentimes just need to prove their nationality. Their unique needs, traits, personalities, circumstances, and fear of persecution are not factored in to determine the scope of their protection and inclusion in the welfare state. The refugees are not perceived as relatable or as persons with whom one can identify. They are not perceived in their entirety, but rather their existence is narrowed down to a single identity-dimension: their nationality. It is this identity dimension that determines their status and rights, sustains their "otherness," and prevents them from ever being perceived as anything but the "other." This corresponds to the literature on the concept of "master status," a term referring to the classification of people into specific social categories based on a single social label, which ultimately delimits their social mobility and ascribes traits, rights, and values to them. ${ }^{88}$

Perhaps as a result, the group-based perception of refugees also prevents them from being appreciated as potential contributing members of society. Instead, emphasis is put on the burdens involved in the protection of these groups of refugees. ${ }^{89}$ The perception of refugees as masses has led to terming their arrival a "tsunami." $" 90$

${ }^{86}$ Refugee Convention, supra note 1, art. 1(C).

${ }^{87}$ Fitzpatrick, supra note 84 , at $300 \mathrm{ff}$.

${ }^{88}$ Everett C. Hughes, Dilemmas and Contradictions of Status. 50 AM. J. Soc. 353 (1945).

${ }^{89}$ See, e.g., Hundreds of Darfur Refugees Flock to Israel, Washington Post, July 13, 2007, available at http://www.washingtontimes.com/news/2007/jul/13/hundreds-of-darfur-refugees-flockto-isr-44735475 ("Israeli municipalities such as Beersheba and Eilat are worried that the refugees might become their financial burden.").

${ }^{90}$ See, e.g., Roni Sofer, Olmert: We Must Curb Infiltrations from Egypt, Mar. 23, 2008, available at http://www.ynetnews.com/articles/0,7340,L-3522476,00.html ("'This is tsunami that can only get worse,' said Olmert. 'We must do everything we can to stop it.' Olmert was reportedly furious by the fact that the problem has yet to be curbed: 'Israel has taken a tough stand with the Palestinian, stopping any of their citizens from entering Israel, and yet thousands have crossed over (to Israel) in a matter of months."'). 
Information, and sometimes misinformation, about quantities and numbers is often used. The motivation behind the arrival of refugees to Israel is questioned and suspected, and they are often called "work infiltrators." In a sense, this resembles the victim-plaintiff distinction Lyotard stretches in the differend situation. ${ }^{91}$ Asylum seekers are unable to present the wrongs that have been committed against them; they are silenced and prevented from speaking since they are not given access to the RSD process; they are not believed since their unheard testimonies are perceived to be, $a$ priori, fictitious covering a reality of economic destitution. It is assumed that if they were resourceful enough to penetrate into the country, then they are not really helpless and worthy of protection. ${ }^{92}$

\section{Detention, Restriction of Freedom of Movement, and Exclusion from Predominant Public LoCI}

Upon entry to Israel, the majority of asylum seekers is detained due to their undocumented entry ${ }^{93}$ and is often held in harsh conditions. ${ }^{94}$ Detentions are carried out under the Entry to Israel Law for most asylum seekers and under the Prevention of Infiltration Law for asylum seekers who are "enemy national." 95 Detention of asylum seekers is not regulated by laws referring specifically to asylum seekers, but rather it is carried out by general immigration laws. This is done despite the fact that the Refugee Convention exempts refugees who present themselves before the authorities without delay from criminal liability for illegal entry. ${ }^{96}$ Detaining asylum seekers also contradicts the UNHCR guidelines on detention ("soft" international law norms), according to which "detention should only be resorted to in cases of necessity" and should "not be automatic, nor should it be unduly prolonged." In other words, the

\footnotetext{
${ }^{91}$ Jean Francois Lyotard, The Differend: Phrases in Dispute (1988).

${ }^{2}$ Id.

${ }^{93}$ Asylum seekers are not detained if the detention centers are at their full occupancy or if they manage to evade the army border control forces. Typically, though, asylum seekers await border control soldiers and do not attempt to infiltrate without being noticed. On occasion, when detention facilities were full, asylum seekers are taken by the soldiers to one of the major cities in the south of Israel and left there. See Bruno Oljveira Martins, Undocumented Migrants, Asylum Seekers and RefugeEs In ISRAEL 13 (2009).

${ }^{94}$ See, e.g., Dan Izenberg, 100 Refugee Kids Held in 'Harsh Conditions' at Ketziot, Jerusalem Post, Jan. 8, 2008 (covering a petition on detention conditions of asylum seekers), available at http://www.hotline.org.il/english/news/2008/JerusalemPost010808-new.htm.

${ }^{95}$ See infra, section D.

${ }^{96}$ Refugee Convention, supra note 1, at art. 31.

${ }^{97}$ UNHCR Guidelines on Detention of Asylum Seekers (Feb. 1999).
} 
special circumstances of asylum seekers, including the necessity that has led them to enter Israel in an undocumented manner, their past trauma, and their legal rights under the Refugee Convention, are not considered at their moment of entry, and they are treated with the same suspicion as other undocumented immigrants. It is often the case that it takes months, sometimes even years, for asylum seekers to be released from detention.

The freedom of movement of the asylum seeker has been restricted not only by means of detention. It has also been limited by different restrictions that were incorporated in the documents provided to asylum seekers. Since the summer of 2008 and until the summer of 2009 , official visa-like papers were distributed to asylum seekers upon their release from detention, according to which they were not allowed to reside, work, or be physically present within the greater Tel Aviv area. The greater Tel Aviv area is where employment is most likely to be found, where most of the humanitarian and human rights organizations that offer assistance to refugees operate, and also where the majority of the Israeli population lives and cultural, commercial, and financial life is concentrated. ${ }^{98}$ These restrictions disrupt the ability of refugee communities to exist. As these visa-like papers were distributed, no special consideration was given to the particular constraints or circumstances of individuals, forcing many individuals to quit their long sought-after jobs, children to drop out of schools, ill individuals to discontinue medical treatment, residents in rented apartments to break their contracts, and so on.

Whether intentionally or unintentionally, the freedom of movement restrictions render refugees marginalized and excluded, and allowed presence only in the periphery, away from the public's eye. Also, these restrictions reflect the notion that refugees need to be curbed, restrained, and contained even after their release from detention. After massive public pressure, the restrictions were cancelled in the summer of 2009, but the government of Israel reserved the right to apply them again. ${ }^{99}$

D. Enemy Nationals and Palestinian Refugees as the Embodiment of the "OTHER"

The most extreme manifestation of the "otherness" of refuges is that of refugee originating from enemy countries and Palestinian refugees. This policy is rather

\footnotetext{
${ }^{98}$ MARTINS, supra note 93.

${ }^{99}$ HCJ 5616/09 African Refugee Development Center v. The Ministry of Interior [Aug. 26, 2009] (unpublished).
} 
unique to Israel. Historically, even before the formation of its asylum system, Israel has had to deal with a number of asylum seekers from enemy countries, ${ }^{100}$ such as Iran, Iraq, ${ }^{101}$ Syria, and Lebanon. Most recently, the large number of persons fleeing the civil war in Sudan has been added to the list. Additionally, Palestinians from the West Bank and Gaza Strip sometimes seek asylum in Israel. All of this is mostly due to the geographical proximity of Israel to its enemy countries. In most cases, these asylum seekers have a rather strong sur place ${ }^{102}$ claim: The mere fact that a person from any of these countries entered Israel and spent some time there is often in itself a reason for that person to suffer from a well-founded fear of being persecuted if returned to his or her home country. ${ }^{103}$

However, Israel refrains from granting refugee status to such asylum seekers or from processing their requests through the RSD process. Before the asylum regulations were enacted, most of the relatively few enemy national asylum seekers received ad hoc UNHCR assistance and were resettled to other countries. However, since the enactment of the asylum regulations in 2002, enemy nationals have been categorized and excluded as a group. The legal basis for this can be found in Article 6 of the Israeli asylum regulations, which reads:

The State of Israel reserves the right, not to absorb into Israel, or to grant a permit to enable the stay in Israel, of subjects of enemy or hostile states - as determined from time to time by the relevant authorities, and for as long as such states possess that status. The issue of the release of such persons on bail will be examined on a case-by-case basis, in accordance with the prevailing circumstances, and security considerations. Israel appreciates the UNHCR's position according to which UNHCR will make every effort to find a country of resettlement for such refugees, pending a comprehensive settlement in the region.

${ }^{100}$ Some difficulties with obtaining refugee status were documented with regard to Egyptian asylum seekers, despite the fact that Israel and Egypt have a peace agreement.

${ }^{101}$ On Iraqi asylum seekers in Israel see HCJ 4702/94 Al-Tai'il v. The Minister of the Interior [1995] IsrSC 49(3) 843.

102 "A person who was not a refugee when he left his country, but who becomes a refugee at a later date, is called a refugee 'sur place." UNHCR, HANDBOoK on PRocedures and CRITERIA for Determining Refugee Status under the 1951 Convention and the 1967 Protocol relating to the Status of Refugees para. 94 (1992); HathawAY, supra note 59, at 41-42.

${ }^{103} \mathrm{See}$ Anat Ben-Dor \& Michael Kagan, The Refugee from my Enemy is my Enemy: The Detention and Exclusion of Sudanese Refugees in Israel, Paper presented to the Minerva Conference on Human Rights (Nov. 19, 2006) (copy on file with author). 
The exclusion of Palestinian asylum seekers is due both to the above-mentioned Article 6 and to a narrow interpretation of the Refugee Convention's Article 1D, which excludes refugees who receive assistance from UN agencies other than UNHCR. Since some Palestinians receive UNRWA assistance, the Israeli government interprets this article, despite the contradicting UNHCR notes, ${ }^{104}$ as excluding all Palestinians from meeting the definition of "refugee" under the Refugee Convention. ${ }^{105}$

There are two reasons for the reluctance of Israel to allow these asylum seekers to obtain status in Israel. First, there is a security reason. The state argues that there is a general presumption of dangerousness that enemy nationals might be involved in terrorism or other types of hostile behavior. Since the state is unable to gather information about the asylum seekers, it resorts to a presumption that they all pose a danger to security. ${ }^{106}$ This presumption follows the logic behind Israeli immigration norms, in particular the logic behind the Nationality and Entry into Israel (Temporary Order) Law, which, as mentioned above, virtually categorically denies any possibility of Palestinian migration and naturalization in Israel due to a presumption of dangerousness. It should be noted, however, that the logic behind the Refugee Convention is very different in the sense that it does not allow discrimination on the basis of nationality, ${ }^{107}$ and it allows the exclusion of refugees solely on the basis of the individual dangerousness they pose. ${ }^{108}$ In this sense, the perceived "otherness" of those refugees coincides with a perceived (or maybe even imagined) "risk."

As Kemp and Goldin deduce from Lupton's arguments on "risk" and "otherness," 109 a person who is perceived to be a "risk" is perceived as such because of his or her "otherness," and "otherness" is perceived as such because of the risk. Refugees are perceived as the "enemy other" not necessarily because of any intrinsic flaw within them, but rather because they are outsiders to the statist legal order and different from the

${ }^{104}$ UNHCR, Revised Note on the Applicability of Article 1D of the 1951 Convention relating to the Status of Refugees to Palestinian Refugees (October 2009).

${ }^{105}$ For an analysis of Article 1D of the Refugee Convention, see Lewis Saideman, Do Palestinian Refugees Have a Right of Return to Israel? An Examination of the Scope of and Limitations on the Right of Return, 44 VA. J. INT'L L. 829, 859 ff (2004); see also KAGAN \& BEN-DoR, supra note 9; TEKKENBERG, supra note 9.

${ }^{106}$ Article 33(d) of the state's response to petitions Anonymous Petitioners v. The Head of the Israeli Defence Forces Operations, supra note 11.

${ }^{107}$ Refugee Convention, supra note 1 , art. 3.

${ }^{108} I d$. art. $1(\mathrm{~F})$.

${ }^{109}$ See Sigal Goldin \& Adriana Kemp, Foreignness and Fertility: On the Bio-Politics of Migration for Employment, Body and Gender, in RACISM IN ISRAEL (2008); DEBORAH LuPTON, Risk and Otherness, in Risk 123 (1999). 
state's nationals. ${ }^{110}$ It should be mentioned that this presumption of the dangerousness of "enemy nationals" has never been rebutted, despite the prolonged presence of many asylum seekers, none of whom has ever been suspected of involvement in securityrelated matters. The presumption has been somewhat relaxed, as enemy national asylum seekers have been released from detention over the course of time.

Another reason for the reluctance of Israel to allow these asylum seekers to obtain status in Israel was given by Israeli officials who have remarked that if asylum seekers are given status in Israel, more individuals will be motivated to come to Israel. This reasoning has been applied with respect to all asylum seekers, but it has had special force in relation to enemy nationals, because their immigration imposes security-related costs and their countries of origin are undemocratic and oppressive. Therefore, there is reason to assume that many enemy nation asylum seekers would be inclined to try to leave their countries of origin. This reasoning also has special force with respect to enemy nationals who are sur place refugees, that is, those who become refugees by virtue of their entry into Israel. ${ }^{111}$ There is a concern, according to officials, that increased immigration would impose a burden on Israel's economy and negatively affect its efforts to maintain its Jewish majority and its Jewish identity. Again, this concern follows the logic of the immigration and citizenship regime, especially the logic behind the Law of Return and the refusal to recognize a right of return of Palestinian refugees. ${ }^{112}$ All this is despite the fact that the Refugee Convention does not allow for the balancing of commitments to refugees against demographic considerations.

The physical presence of the enemy national is almost unchallenged. Generally, Israel refrains from forcefully returning these asylum seekers to their countries of origin. ${ }^{113}$ Also, although initially Israel tried to resettle enemy nationals in safe third countries, it is currently unable and unwilling to do so, given the scope of the phenomenon and a lack of desire to encourage further immigration from these countries by institutionalizing resettlement solutions. ${ }^{114}$

${ }^{110}$ Carl Schmitt, The Concept of the Political 19-35 (1976).

"11' See supra note 104.

${ }^{112}$ See supra note 24.

${ }^{113}$ On a number of occasions, Israel did, in fact, deport persons to Egypt, which later deported them to their countries of nationality. See Refugee Rights Forum 2008, IDF Keeps on Expelling Asylum Seekers to Egypt Despite Egypt's Declarations to the Media that they will be Deported to Their Homelands, available at http://www.hotline.org.il/english/news/2008/Hotline090308.htm. This policy is currently challenged in a petition that is pending before the Supreme Court in HCJ 7302/07 The Hotline for Migrant Workers v. The Minister of Defense.

${ }^{11+}$ This was mentioned by the honorary senior officer of the UNHCR, Mr. Michael Bavli, in his talk with the Refugee Rights Clinic, Mar. 20, 2007. 
However, despite the obvious and rather stable physical presence of enemy national refugees in Israel, their legal and social presence is compromised, ${ }^{115}$ both as a result of their perceived otherness and as a reinforcement of it. A series of obstacles prevents enemy nationals from integrating into Israeli society. First, because enemy nationals are governed by the above-mentioned legal norms, their asylum applications are not processed, and they are unable to receive protection based on their individual fear of being persecuted. As a result, most enemy nationals are left in legal limbo, ${ }^{116}$ finding undocumented employment or being employed through informal arrangements between governments and employers. ${ }^{117}$

Second, enemy nationals are treated as a group, not as individuals. This is apparent in they are viewed through the prism of a generalized presumption of dangerousness. Since a list of enemy countries for the purpose of these regulations has never been formed, it seems that the decision of who is "the enemy" is dependent, in large, on the question of who is asking for asylum. In other words, rather than being perceived as nationals of particular countries, they are viewed as the "enemy other." The only case of enemy nationals receiving a meaningful form of protection in Israel is a finite group of approximately 600 refugees from Darfur, which received a group-based form of protection, outside the scope of the Refugee Convention. ${ }^{118}$ It is this group view of enemy national asylum seekers that prevents the realization that there is no information linking individual asylum seekers to terrorism or other security threatsas must have been realized by the authorities who granted status to the 600 Darfurians without any security screening. Moreover, this group view does not allow for people to identify with the asylum seekers' fear of persecution or harsh feelings toward their governments (which are the enemies of Israel) and does not allow any empathy for the 601 st Darfurian, whose need for protection is in no less than the 600 previous Darfurians.

Third, enemy nationals are typically detained as infiltrators under the Prevention of Infiltration Law, a piece of emergency legislation which, according to the state, is applied mostly to enemy nationals. Asylum seekers who are nationals of nonenemy countries are detained under a different law, ${ }^{119}$ or, at most, detained under the

\footnotetext{
115 Compare with Giorgio Agamben, Homo SAcer: Sovereign Power and Bare Life (1998).

${ }^{116}$ See, e.g., IRIN, ISRAEL: Asylum-Seekers Detained, Harassed, Feb. 4, 2009, available at http://www.irinnews.org/Report.aspx?ReportId=82739.

117 See letter from the UNHCR office in Tel Aviv, supra note 73.

${ }^{118}$ Id.

${ }^{119}$ Entry into Israel Law, supra note 32.
} 
infiltration law only for a short period of time, before having their detention reframed under a different law. ${ }^{120}$ While detention under the emergency legislation is not subject to judicial review, quasi-judicial review was implemented following a habeas corpus petition to the Israeli Supreme Court. ${ }^{121}$ This has led in the past to conditional releases of enemy nationals from detention ${ }^{122}$ (most typically to employers who employed them in an undocumented manner or under some informal understanding with government officials). ${ }^{123}$

Thus, as mentioned above, the enemy national asylum seeker is the most disadvantaged immigrant, as is the Palestinian and Arab immigrant to Israel. Enough attention has not been devoted to the differences between the two groups in the circumstances of their immigration or the norms that govern their rights.

\section{ConcLusion}

Israel's asylum system is still evolving, and it seems to use Israel's immigration and citizenship system as its main normative reference point rather than international refugee law, while compromising the scope of the protection for refugees. ${ }^{124}$ The result is a massive exclusion of asylum seekers, who are not rendered physically absent, but rather they are rendered absent from the legal order and social life and denied political visibility. While this phenomenon is not uncommon in today's world, which suffers from "compassion fatigue," 125 diluted protection, and adherence to national self-interest, the Israeli example is exceptional for a number of reasons. It is exceptional since it is delayed and came into being only decades after the rest of the democratic developed countries developed their asylum systems. It is also exceptional because it is rooted in challenging - albeit not exceptional-geo-political conditions and because it works against the background of a very unique immigration law.

${ }^{120}$ Recently, the detention of enemy nationals is being regulated under the Entry into Israel Law after the first ten days of detention. See Anonymous Petitioners v. The Head of the Israeli Defence Forces Operations, supra note 11 (interim decision delivered by the Court) [Oct. 7, 2008].

${ }^{121}$ See id. (petition) [submitted Apr. 2006] (copy on file with author).

${ }^{122}$ See id. (Respondents' response to the petition) [June 18, 2008] (copy on file with author).

${ }^{123}$ See Letter from the UNHCR office in Tel Aviv, supra note 73.

${ }^{124}$ In this Article, the term "refugee law," refers to the Refugee Convention, the 1967 Protocol Relating to the Status of Refugees, 606 U.N.T.S. 8791, several regional instruments, and other "soft law" norms that developed later, such as UNHCR handbook and guidelines, which are a semiauthoritative source of interpretation of the other refugee law norms.

${ }^{125}$ Maryellen Fullerton, The International and National Protection of Refugees, in GuDE to International Human Rights Practice 245, 247 (Hurst Hannum ed., 4th ed. 2004). 
As the Israeli asylum system becomes more elaborate, it is constantly challenged by the civil society. Future research should follow the asylum system as it develops past this embryonic stage to see whether it maintains the logic of the immigration and citizenship regime and continues to portray the refugee as the "other"- or whether it detaches itself from immigration law and establishes a logic of its own, grounded in international law. 